\title{
Influence of wavelength on the laser removal of lichens colonizing heritage stone
}

M. Sanz ${ }^{1 *}$, M. Oujja ${ }^{1}$, C. Ascaso ${ }^{2}$, S. Pérez-Ortega ${ }^{3}$, V. Souza-Egipsy ${ }^{4}$, R. Fort ${ }^{5}$, A. de los Rios ${ }^{2}$, J. Wierzchos ${ }^{2}$, M. V. Cañamares ${ }^{4}$, M. Castillejo ${ }^{1}$

${ }^{1}$ Instituto de Química Física Rocasolano (IQFR-CSIC), Serrano 119, 28006 Madrid, Spain

${ }^{2}$ Museo Nacional de Ciencias Naturales (MNCN-CSIC), José Gutiérrez Abascal 2, 28006, Madrid, Spain

${ }^{3}$ Real Jardín Botánico (RJB-CSIC), Plaza de Murillo 2, 28014 Madrid, Spain

${ }^{4}$ Instituto de Estructura de la Materia (IEM-CSIC), Serrano 121, 28006 Madrid, Spain

${ }^{5}$ Instituto de Geociencias (IGEO-CSIC, UCM), José Antonio Nováis 12, 28040 Madrid, Spain

* Corresponding author: mikel.sanz@iqfr.csic.es

\section{Abstract}

Laser irradiation of lichen thalli on heritage stones serves for the control of epilithic and endolithic biological colonizations. In this work we investigate rock samples from two quarries traditionally used as source of monumental stone, sandstone from Valonsadero (Soria, Spain) and granite from Alpedrete (Madrid, Spain), in order to find conditions for efficient laser removal of lichen thalli that ensure preservation of the lithic substrate. The samples presented superficial areas colonized by different types of crustose lichens, i.e. Candelariella vitellina, Aspicilia viridescens, Rhizocarpon disporum and Protoparmeliopsis muralis in Valonsadero samples and P. cf. bolcana and A. cf. contorta in Alpedrete samples. A comparative laser cleaning study was carried out on the mentioned samples with ns Q-switched Nd:YAG laser pulses of $1064 \mathrm{~nm}$ (fundamental radiation), $355 \mathrm{~nm}$ (3rd harmonic) and $266 \mathrm{~nm}$ (4th harmonic) and sequences of IR-UV pulses. A number of techniques such as UV-Vis absorption spectroscopy, stereomicroscopy, scanning electron microscopy (SEM), SEM with backscattered electron imaging (BSE), electron dispersive spectroscopy (EDS) and FTRaman spectroscopy were employed to determine the best laser irradiation conditions and to detect possible structural, morphological and chemical changes on the irradiated surfaces.

The results show that the laser treatment does not lead to the complete removal of the studied lichen thalli, although clearly induces substantial damage, in the form of loss of the lichen upper cortex and damage to the algal layer. In the medium term these alterations could result in the destruction of the lichen thalli, thus providing a degree of 
control of the biodeterioration processes of the lithic substrate and reducing the chances of subsequent lichen recolonization.

Keywords: laser removal, lichens, biodeteriogen layer, stone, conservation

\section{Introduction}

Free living microorganisms as fungi, algae, cyanobacteria and non-photosynthetic bacteria, as well as lichens, symbiotic associations between fungi and algae/cyanobacteria, represent the main biodeterioration agents on stone substrates [13]. Highlighting recent studies on photoautotrophic microbiota, it has been found that algae are responsible of a certain degree of aesthetic damage, leading to the green staining of surfaces. In contrast, cyanobacteria can also induce endolithic damage, altering crystalline surfaces of the stone $[4,5]$. Generally, the internal regions of the lithic substrate are also subjected to colonization by endolithic fungi that lead to significant physical and chemical effects and at times result in considerable substrate damage $[6,7]$. On the other hand, lichens can affect the surface of the stone and can also penetrate deep into the substrate, promoting physical and chemical changes [8]. As epilithic and endolithic colonizers play an important role in biodeterioration of stone, microscopic techniques are necessary to evaluate their action. In situ microscopy, which consist of simultaneously applying several microscopy techniques without separating the biological component from its habitat [9], allows characterization of the biofilms involved in biodeterioration and reveals the biogeophysical and biogeochemical impact of biodeteriogen agents.

The effective removal of microbial colonization is necessary for the preservation of stone heritage. Mechanical treatments often fail to protect the substrate integrity and the application of biocides, apart from involving environmental toxicity issues, is not always completely effective to eliminate biodeteriogens $[1,2]$. The main problem detected during biocide treatment of lichens encrusted on stone heritage is that considerable portions of lichen thalli remain attached to the substrate, even after several weeks of application of highly concentrated biocides, usually applied with bristle brushes or in the form of poultices $[1,2,10]$. In previous treatments of lichen encrustations, a mixture of dead and living microorganisms was found after biocide application. These included living fungal forms in stone cracks and debris of dead, free- 
living and lichenized fungi [11]. Other treatments were effective for cyanobacteria, but with unequal effects in lichen and endolithic fungi $[11,12]$.

Laser cleaning constitutes a promising alternative to more conventional cleaning techniques for certain applications. In the field of cultural heritage, it is a well established technique, allowing fine and selective removal of superficial deposits and encrustations [10, 13-25]. Laser irradiation can be used for antifouling purposes, causing mortality to biofilm forming microorganisms, like marine bacteria and microalgae $[26,27]$. When applied to the treatment of lichen encrustations on stone, and although laser cleaning fails to completely remove lichen thalli, superficial lichen debris can be brushed away without affecting the substrate surface [10, 28, 29]. When applied to microbial colonization on stone, the laser cleaning approach requires a physical parametrization, associated with a detailed petrographic and mineralogical diagnosis of the effects induced on the substrates, allowing the determination of the irradiation thresholds for damage phenomena and the understating of the nature of the effects on biodeteriogens and stones [28, 30-32]. Depending on the microorganism type and species involved, different complex interactions with the rock minerals are observable $[6,7]$.

Some laser cleaning studies have focused on the removal from stone of biodeteriogen agents such as epilithic lichen and fungi [10, 28-34]. It has been shown that Er:YAG laser irradiation (at $2.94 \mu \mathrm{m}$ ) produces cellular destruction in the lichen Diploschistes scruposus due to the laser wavelength coincidence with the $\mathrm{OH}$ absorption band of either intrinsic or extrinsic water [28]. A rapid heat transfer to lichen thalli could take place when the laser wavelength is in resonance with light absorption bands of biodeterioration layers. For the lichen species Verrucaria nigrescens, Q-switched nanosecond Nd:YAG laser irradiation causes the partial removal of lichen thalli, with clear structural and ultrastructural alterations, including the ablation of the lichen upper cortex and part of the medulla and the plasmolysis of endolithic fungal cells [32]. These effects are probably due to the high concentration of endogenous or exogenous absorbing compounds at $1064 \mathrm{~nm}$. A study of the effect of pulse duration and wavelength of $\mathrm{Nd}$ :YAG laser in the elimination of $V$. nigrescens from Carrara marble substrates has shown the advantages of irradiation at $532 \mathrm{~nm}$, mainly due to the corresponding high optical absorption of the fungal melanin compound [30, 34], with the ensuing disruptive photothermal and photomechanical effects. Very recently, some of us [31] compared different Q-switched ns Nd:YAG irradiation modes based on 
single-wavelength irradiation, at $1064 \mathrm{~nm}$ and at $355 \mathrm{~nm}$, and on a double wavelength irradiation consisting in sequences of a number of $1064 \mathrm{~nm}$ pulses followed by the same number of $355 \mathrm{~nm}$ pulses. We showed that this sequential IR-UV laser treatment ensures effective removal of lichen thalli and damage in the microbial cells, thus providing a method for effective elimination of crustose epilithic lichens.

In this work, samples of sandstone from Valonsadero (Soria, Spain) [35] and of granite from Alpedrete (Madrid, Spain) [36] were investigated in order to find the conditions for efficient laser removal of crustose lichens, typically colonizing these two types of lithic substrates. The selected stone types are traditionally used in heritage buildings and monuments in central Spain and the samples studied presented superficial areas colonized by different crustose lichens, i.e. Candelariella vitellina, Aspicilia viridescens, Rhizocarpon disporum and Protoparmeliopsis muralis in Valonsadero samples and $P$. cf. bolcana and A. cf. contorta in Alpedrete samples. These species show a wide range of anatomical structures and a diverse set of secondary compounds. UV-Vis absorption spectra of the biodeteriogen layer diluted in ethanol and identification of the lichen secondary compounds by thin layer chromatography (TLC) served to determine the best laser wavelengths for irradiation of each biodeteriogen species. A laser cleaning study was carried out on the mentioned samples with ns Qswitched Nd:YAG laser pulses of $1064 \mathrm{~nm}$ (fundamental radiation), $355 \mathrm{~nm}$ ( $3^{\text {rd }}$ harmonic) and $266 \mathrm{~nm}\left(4^{\text {th }}\right.$ harmonic) at fluences just below the previously determined ablation thresholds of the bare stone samples.

A number of techniques were employed to detect morphological and chemical changes on the irradiated surfaces. Stereomicroscopy was used to describe morphological and colour changes, scanning electron microscopy (SEM) at low vacuum served to analyse the effects on the surface of the lichens, while SEM with backscattered electron imaging (SEM-BSE) and electron dispersive spectroscopy (EDS) microanalyses of the polished transversal cross sections were applied to assess effects inside the lichen layer. FTRaman spectroscopy was employed to detect possible structural and chemical changes of stone substrates.

\section{Experimental and Methodology}

The present study was carried out on sandstone samples consisting of quartz (60-85\%), $\mathrm{K}$ feldspar (10-30\%) and mica (2-5\%) [35] and granite samples consisting of 
interlocking plagioclase aggregates (20-30\%), quartz (30-40\%), K feldspar (25-35\%) and biotite (10-20\%) [36].

Elemental chemical analysis of the two stone types was carried out using between 8 and $15 \mathrm{~kg}$ of fresh rock samples, that were dissolved in a mixture of $\mathrm{HF}$ and $\mathrm{HClO}_{3}$ in platinum crucibles. Major elements were determined by inductively coupled plasma atomic emission spectroscopy (ICP-AES) using a Jovin-Yvon 38 plus spectrometer. $\mathrm{FeO}$ was determined by titration.

According to these measurements, the chemical composition (in wt \%) of sandstone samples was: $\mathrm{SiO}_{2}$ (76.0), $\mathrm{AI}_{2} \mathrm{O}_{3}$ (10.0), $\mathrm{Fe}_{2} \mathrm{O}_{3}$ (5.9), $\mathrm{K}_{2} \mathrm{O}$ (3.6), $\mathrm{Na}_{2} \mathrm{O}$ (0.24), $\mathrm{CaO}$ (0.06), $\mathrm{MgO}$ (0.08), $\mathrm{TiO}_{2}(0.23), \mathrm{SO}_{3}(<0.03)$ and of granite samples: $\mathrm{SiO}_{2}$ (69.6), $\mathrm{AI}_{2} \mathrm{O}_{3}$ (15.02), $\mathrm{Fe}_{2} \mathrm{O}_{3}$ (2.97), $\mathrm{FeO}$ (1.54), $\mathrm{K}_{2} \mathrm{O}$ (3.89), $\mathrm{Na}_{2} \mathrm{O}$ (3.32), $\mathrm{CaO}$ (2.45), $\mathrm{MgO}$ (0.96), $\mathrm{TiO}_{2}(0.4), \mathrm{P}_{2} \mathrm{O}_{5}(0.16), \mathrm{MnO}(0.05)$. These values are the result of averaging over a high number of samples of the same stone and are affected by less than $1 \%$ error. It has to be noticed that the $\mathrm{CaO}$ concentration of granite is considerably higher than that of the sandstone, a factor that can influence the lichen removal, as it will be seen in the Results and Discussion section.

As mentioned, sandstone samples were colonized by the crustose lichen species Candelariella vitellina (yellow-orange), Aspicilia viridescens (greenish grey), Rhizocarpon disporum (grey brown) and Protoparmeliopsis muralis (yellowish green) and granite samples were colonized by the also crustose lichens $P$. cf. bolcana (yellowish green) and $A$. cf. contorta (greenish grey).

To determine the best laser wavelength for irradiation in each case, we employed a double approach. First, we measured the UV-Vis absorption spectra of extracts of lichen layers. To that purpose, we dissolved ca. $1 \mathrm{~cm}^{2}$ of each lichen sample in $5 \mathrm{~mL}$ of pure ethanol during 16 hours. The resulting suspensions were then filtered with a $0.2 \mu \mathrm{m}$ Millipore syringe filter. Spectra were measured in the $200-1100 \mathrm{~nm}$ range with a double-beam spectrophotometer (Shimadzu UV-3600) using $1 \mathrm{~cm}$ optical path quartz cuvettes for both the sample and for the pure ethanol reference. Second, we identified lichen secondary compounds by TLC following the method of Orange et al. [37]. In brief, ca. $1 \mathrm{~cm}^{2}$ of each lichen species was immersed in $400 \mu \mathrm{L}$ of acetone during 60 min. The extracts were applied in two $20 \times 20 \mathrm{~cm}^{2}$ glass silica gel plates (Merck 100390) using solvents $A$ and $\mathrm{C}$ [37]. Plates were finally revealed using $10 \% \mathrm{H}_{2} \mathrm{SO}_{4}$ and inspected under UV light. Lichen compounds were identified through their retention factors. 
We applied sequences of laser pulses to hydrated areas of the lichen thalli that were previously selected under a Leica EC3 stereomicroscope equipped with a NIKON COOLPIX 8800 VR camera, according to their homogeneity and good shape. Stereomicroscopy was also used to detect morphological and colour surface changes produced upon irradiation. The samples were maintained under controlled low humidity conditions before and after laser irradiation.

Irradiation tests were carried out with a Q-switched Nd:YAG laser (pulse width $17 \mathrm{ns,}$ repetition frequency $1-10 \mathrm{~Hz}$ ) using the fundamental wavelength of 1064 and its third and fourth harmonic at 355 and $266 \mathrm{~nm}$, respectively. We applied sequences of 100 pulses at either individual IR or UV wavelengths or sequences of 100 IR pulses followed by another $100 \mathrm{UV}$ pulses under the same irradiation path. The unfocussed laser beams, with a cross section of ca. $0.25 \mathrm{~mm}^{2}$, were directed to the surface of the sample with the help of mirrors and the pulse energy was measured with a joulemeter (Gentec ED-200). The laser fluences used for irradiation of the samples were $1.8 \mathrm{~J} \mathrm{~cm}^{-2}$ for $1064,0.4 \mathrm{~J} \mathrm{~cm}^{-2}$ for 355 and $0.2 \mathrm{~J} \mathrm{~cm}^{-2}$ for $266 \mathrm{~nm}$, respectively, values just below the ablation threshold of both bare sandstone and granite lithotypes. During irradiation, the samples were translated perpendicularly to the laser propagation direction to obtain uniformly irradiated areas of up to $1 \mathrm{~cm}^{2}$.

After irradiation and examination by stereomicroscopy, the stone samples were prepared for SEM-BSE observation using the method developed by Wierzchos and Ascaso [38]. This technique allows for the fine monitoring of the changes in the anatomy of the epilithic lichen thalli and in the morphological alterations of the photobiont and mycobiont cells induced under the different laser irradiation conditions. Briefly, the stone samples, were cut transversely, fixed, dehydrated, embedded in resin and fine-polished after polymerization. The fine-polished surfaces of the stone sample cross-sections were carbon coated and finally examined using a SEM (FEI Inspect, Hillsboro, USA) equipped with a solid-state, four diodes BSE detector plus an auxiliary X-ray EDS microanalytical system (INCA, Oxford, UK). Optimum conditions of observation were obtained at an accelerating potential of $15-20 \mathrm{kV}$, a working distance of $8-10 \mathrm{~mm}$ and specimen current of $10^{8} \mathrm{~A}$.

For FT-Raman spectroscopic measurements, we used a RFS 100/S-G Bruker spectrometer equipped with a cooled Ge detector. The excitation source consists of a 
continuous Nd:YAG laser emitting at $1064 \mathrm{~nm}$. We applied controlled laser power outputs (20-50 $\mathrm{mW})$ to avoid damage of the samples during measurements. The light scattered from an area of $<0.01 \mathrm{~cm}^{2}$ was collected in backscattering $\left(180^{\circ}\right)$ geometry. Each data point resulted from the accumulation of 500 scans and the wavenumber resolution was $4 \mathrm{~cm}^{-1}$.

\section{Results and discussion}

\subsection{Characterization of lichens}

The different laser irradiation conditions lead to different degrees of thalli removal, highly depending on the lichen species treated and on the type of stone substrate. The efficiency of laser damage depends on the laser-material interaction, which in turn, is related to wavelength, fluence and optical properties of the sample, such as absorption of light and heat diffusion [19, 21, 28, 30-32]. The wavelength of $1064 \mathrm{~nm}$ was selected because it is known to produce ultrastructural changes in endolithic mycobiont hyphae and also in free living fungi and algae lying inside the stone substrate [32]. UV laser wavelengths were chosen depending on the UV-Vis absorption spectra of ethanol extracts of each lichen species and on the lichen compounds identified by TLC.

Figure 1 shows the absorption spectra in the $200-500 \mathrm{~nm}$ range of the biodeterioration layer extracted in ethanol for some of the lichens studied. All the lichen samples present a higher absorbance at 266 than at $355 \mathrm{~nm}$, and in the case of $P$. muralis, the absorbance is considerably higher at the shorter wavelength ( 0.88 at 266 and 0.2 at $355 \mathrm{~nm})$. P. cf. bolcana and A. viridescens $\mathrm{UV}-\mathrm{V}$ is spectra are not shown because they are very similar to those obtained from $P$. muralis and A. cf. contorta, respectively. The solution obtained from $C$. vitellina presented a strong yellow colour and it was necessary to obtain an ethanol solution with a concentration 10 times lower in order to avoid saturation of the absorbance. As observed in this figure, the absorbance of the Aspicilia lichen is very low at wavelengths longer than $220 \mathrm{~nm}$. For wavelengths larger than 500 $\mathrm{nm}$, the absorbance is negligible in all cases (not shown). 


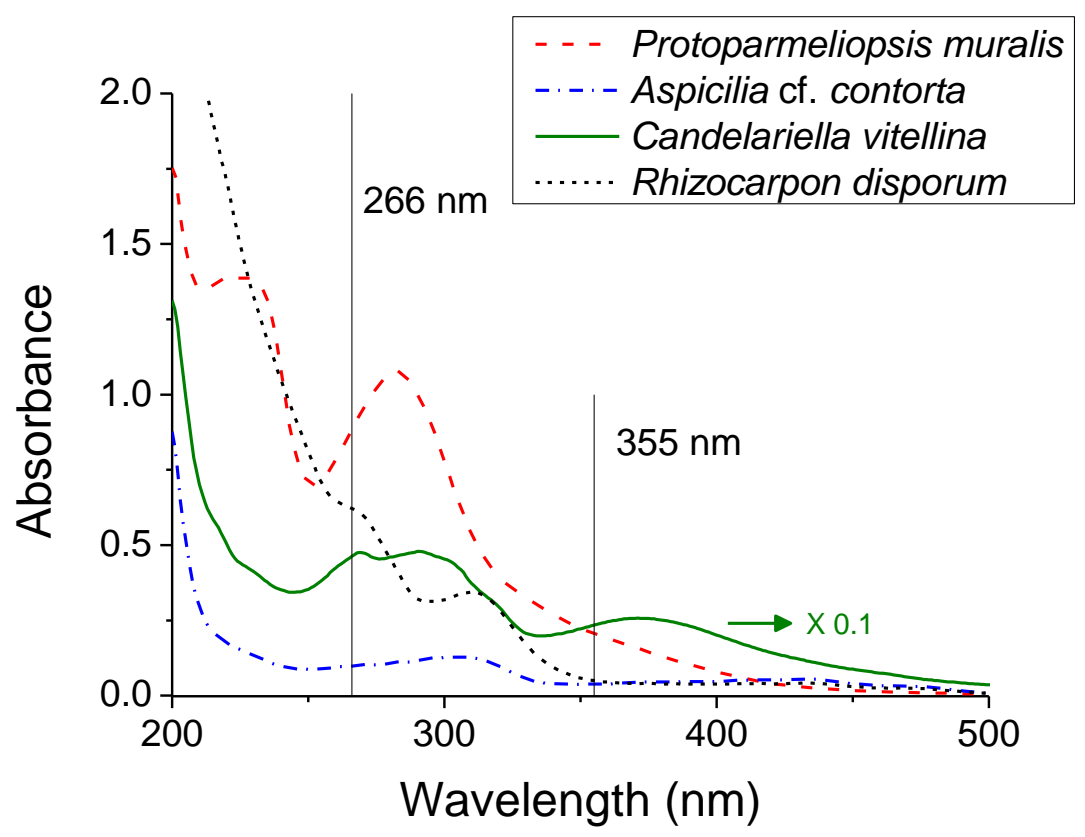

Fig. 1. Optical absorption spectra of solutions obtained upon diluting the indicated lichen layers in ethanol. Solution from $C$. vitellina was dissolved ten times more in pure ethanol.

TLC analyses revealed the following lichen substances by species: calycin and pulvinic acid lactone in $C$. vitellina, traces of norstictic acid in $R$. disporum, usnic and psoromic acids, zeorin and two unidentified substances in $P$. muralis and $P$. cf. bolcana. All these lichen compounds absorb UV radiation in the explored spectral range (Fig. 1) [39]. No substances were detected by TLC in A. cf. contorta and A. viridescens. The identified lichen compounds are listed in Table 1, together with the absorption wavelength range and the corresponding molar attenuation coefficients.

Table 1. Lichen compounds identified for each lichen species with the absorption wavelength $\left(\lambda_{\text {abs }}\right)$ range [39] and the corresponding molar attenuation coefficient ( $\varepsilon$ ). Data taken from [39].

\begin{tabular}{|l|c|c|c|}
\hline \multicolumn{1}{|c|}{ Lichen } & Lichen compounds & $\boldsymbol{\lambda}_{\text {abs }}(\mathbf{n m})$ & $\boldsymbol{\varepsilon}\left(\mathbf{L} \mathbf{~ m o l}^{\mathbf{1}} \mathbf{~ c m}^{\mathbf{- 1}}\right)$ \\
\hline $\begin{array}{l}\text { Candelariella } \\
\text { vitellina }\end{array}$ & $\begin{array}{c}\text { Calycin } \\
\text { Pulvinic acid lactone }\end{array}$ & $236-291$ & $11749-54954$ \\
$1316-389$ & -31623 \\
\hline $\begin{array}{l}\text { Aspicilia viridescens } \\
\text { and A. cf. contorta }\end{array}$ & Non-detected & - & - \\
\hline Rhizocarpon & Traces of nortistic & $250-270$ & $1995-18620$ \\
disporum & acid & $295-333$ & $8710-39810$ \\
\hline $\begin{array}{l}\text { Protoparmeliopsis } \\
\text { muralis and P. cf. }\end{array}$ & Usnic acid & $282-290$ & $21380-32359$ \\
\cline { 2 - 4 } bolcana & Psoromic acid & $208-240$ & - \\
\cline { 2 - 4 } & Zeorin & - & - \\
\hline
\end{tabular}

Taking into account these results, and with the help of visual and stereomicroscopic observations of laser irradiated samples, we defined the laser conditions for removal of 
the colonization layers. For UV irradiation, the wavelength of $266 \mathrm{~nm}$ was selected, except for samples colonized by $P$. muralis. In this case, irradiation at $355 \mathrm{~nm}$ was preferred due to the lower absorbance at this wavelength, a selection that served to assess the effect of laser absorption by the sample. The laser irradiation fluences were chosen to be just below the damage threshold of the bare stone substrates. Irradiation conditions for each sample are presented in Table 2.

Table 2. Laser irradiation conditions for each sample. (S) stands for sandstone and (G) for granite.

\begin{tabular}{|c|c|c|c|c|c|}
\hline Lichen & $\begin{array}{l}1064 \mathrm{~nm}^{-2} \\
1.8 \mathrm{~J} \mathrm{~cm}^{-2}\end{array}$ & $\begin{array}{l}355 \mathrm{~nm} \\
0.4 \mathrm{~J} \mathrm{~cm}^{-2}\end{array}$ & $\begin{array}{l}266 \mathrm{~nm}^{-2} \\
0.2 \mathrm{~J} \mathrm{~cm}^{-2}\end{array}$ & $\begin{array}{l}1064+355 \mathrm{~nm} \\
1.8-0.4 \mathrm{~J} \mathrm{~cm}^{-2} \\
\end{array}$ & $\begin{array}{l}1064+266 \mathrm{~nm} \\
1.8-0.2 \mathrm{~J} \mathrm{~cm}^{-2}\end{array}$ \\
\hline $\begin{array}{l}\text { Candelariella } \\
\text { vitellina }(\mathrm{S})\end{array}$ & X & & $X$ & & $\mathrm{X}$ \\
\hline $\begin{array}{l}\text { Aspicilia } \\
\text { viridescens }(\mathrm{S})\end{array}$ & $X$ & & $X$ & & $X$ \\
\hline $\begin{array}{l}\text { Rhizocarpon } \\
\text { disporum }(\mathrm{S})\end{array}$ & $X$ & & $\mathrm{X}$ & & $\mathrm{X}$ \\
\hline $\begin{array}{l}\text { Protoparmeliopsis } \\
\text { muralis }(\mathrm{S})\end{array}$ & $X$ & $X$ & & $X$ & \\
\hline $\begin{array}{l}\text { Protoparmeliopsis } \\
\text { cf. bolcana }(\mathrm{G})\end{array}$ & $X$ & & $X$ & & $X$ \\
\hline $\begin{array}{l}\text { Aspicilia } \\
\text { cf. contorta }(\mathrm{G})\end{array}$ & $X$ & & $X$ & & $X$ \\
\hline
\end{tabular}

\subsection{Microscopy analysis of treated samples}

The structural modifications of the biodeteriogens were screened by stereomicroscopy. Figure 2 illustrates the effect of laser irradiation on $C$. vitellina on sandstone. Specifically, Figure 2a shows an area of the non-treated sandstone sample colonized by this lichen species, Figures $2 b$ and $2 c$ show areas of the sample irradiated at 1064 and $266 \mathrm{~nm}$, respectively. The $1064 \mathrm{~nm}$ laser treatment (Fig. 2b) induces a superficial change of colour of the lichen from the initial yellow-orange to a greenish orange tone, that is consequence of the partial removal of the lichen upper cortex in most of the treated thalli. The laser treatment also removes small portions of the thalli in some areas (white-grey spots in Fig. 2b). On the other hand, UV irradiation (Fig. 2c) induces more pronounced effects on the lichen. The superficial green tone is due to the uncovering of the algal layer. Other changes are also observable, i.e. hymenial tissue was partially ablated from lichen apothecia (fungal reproductive structures), although excipular tissues remained, as indicated in the figure by a white arrow. UV laser irradiation also 
induces the complete removal of large areas of the thalli (white-grey zones). For this species, the higher removal efficiency by UV irradiation is mainly attributable to the higher optical absorption of the compounds present in this lichen species (Fig. 1), which triggers damage through photomechanical effects [30].
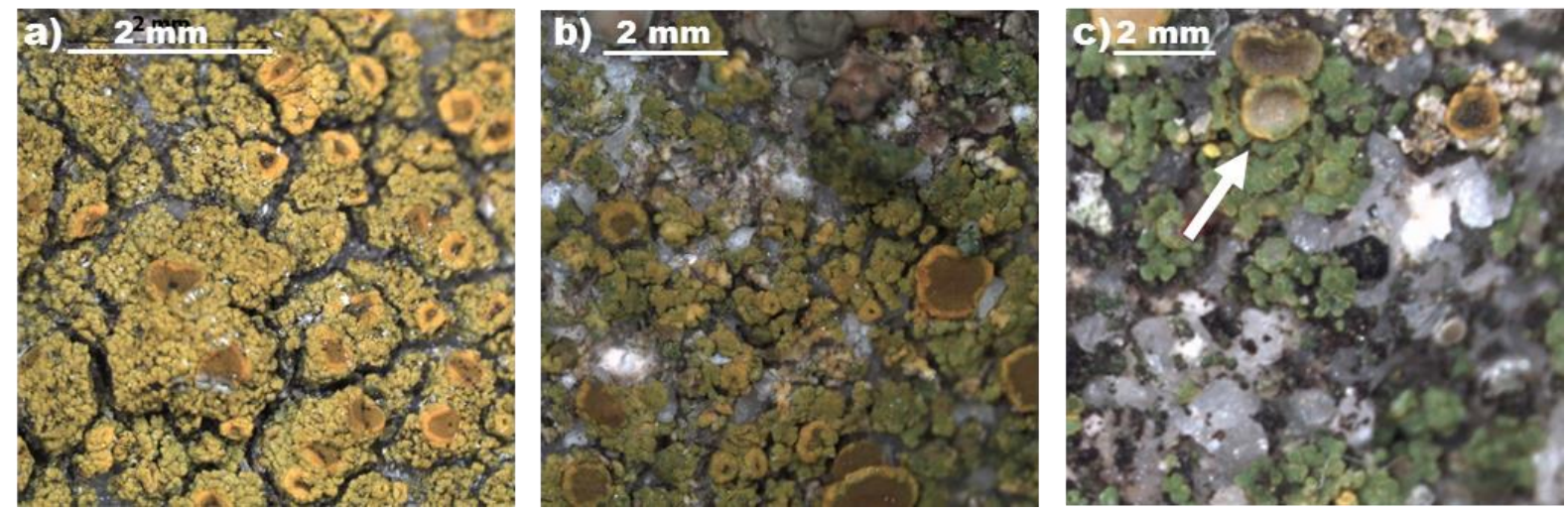

Fig. 2. Stereomicroscopy images of C. vitellina on sandstone: a) non-treated, b) irradiated with 100 pulses of $1064 \mathrm{~nm}$ and c) irradiated with 100 pulses of $266 \mathrm{~nm}$. The white arrow in c) indicates partially ablated apothecia. For interpretation of the references to colour in this figure, the reader is referred to the web version of the article.

Figure 3 displays the effect of laser irradiation of A. viridescens on sandstone. Figure $3 \mathrm{a}$ shows a non-treated area of the sample (above the red fringe) and an area irradiated with $1064 \mathrm{~nm}$ pulses followed by pulses of $266 \mathrm{~nm}$ (below the red fringe). On the surface of the treated part, the green colour corresponding to the algal layer is clearly visible by stereomicroscopy. Further, upper hymenium in apothecia appears changed from a blackish colour to a light brown tone (full white arrow). SEM-BSE images show that IR-UV dual laser irradiation leads to the partial removal of some areoles, exposing the basal lipid-rich medullar fungal cells (Fig. 3b, left of the full white arrow). Further, in some areas, complete removal of the areoles was observed. For this sample, the presence of lipid bodies (marked with an open white arrow) in fungal hyphae is evident, both in non-treated and laser treated areas.

In previous laser removal studies of Verrucaria nigrescens on a dolostone substrate [32] it was found that IR laser irradiation was adequate for the alteration of fungal lipid bodies. In contrast, in the case of $A$. viridescens the laser irradiation at $1064 \mathrm{~nm}$ (not shown) resulted in the partial removal of the upper cortex, while he lipid bodies of the exposed fungi remained unaltered. This difference is possibly related with the higher 
fluences used for treating $V$. nigrescens $\left(2 \mathrm{~J} \mathrm{~cm}^{-2}\right.$ ) [32], conditions that were allowed as dolostone presents a higher ablation threshold than sandstone at this wavelength.
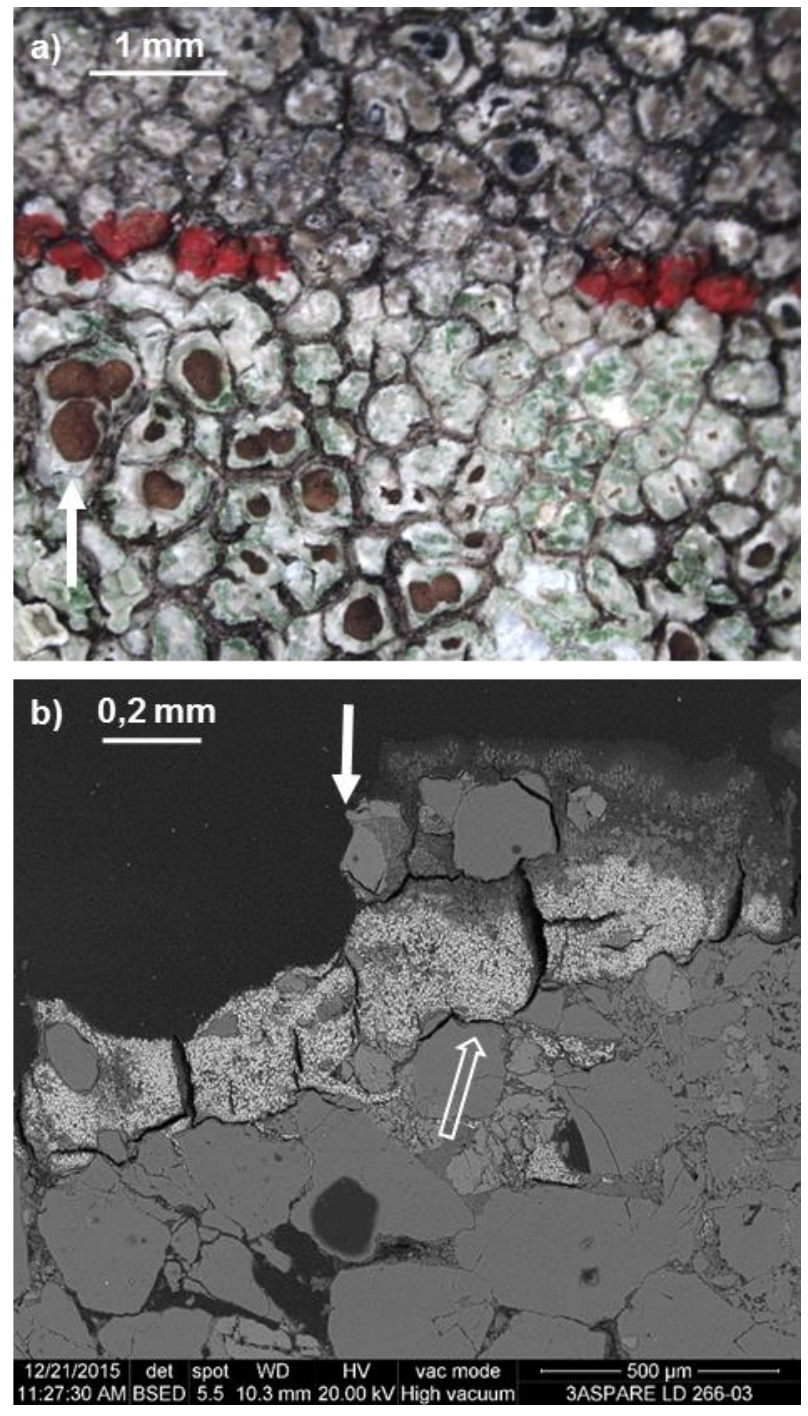

Fig. 3. Images of A. viridescens on sandstone: a) stereomicroscopy image of the non-treated zone (above the red fringe) and treated by sequential IR-UV irradiation $(1064+266 \mathrm{~nm}$, below the red fringe), b) SEM-BSE image of non-treated sample (right of the full white arrow) and irradiated (left of the full white arrow) as indicated in a). The open white arrow signals the presence of lipid bodies. For interpretation of the references to colour in this figure, the reader is referred to the web version of the article.

For $R$. disporum on sandstone (Fig. 4a), the sequential IR-UV $(1064+266 \mathrm{~nm})$ dual laser irradiation (Fig. 4b) induced the partial removal of the lichen upper cortex and exposure of the algae, as put in evidence by the green colour of the irradiated area. SEM images of the superficial parts of the thalli in a non-treated zone (Fig. 4c) and in the irradiated zone (Fig. 4d) reveal further details of the effects of the IR-UV dual laser treatment. The areoles from the non-irradiated thalli (Fig. 4c) show an uneven 
continuous surface, characteristic of the amorphous layer of polysaccharides that constitute the upper part of the cortex. Figure $4 d$ shows how the laser treatment eliminates this layer, leaving a network of small holes which correspond to damaged fungal cells from the cortex. The partial removal of the cortex induced by IR-UV irradiation is confirmed by the SEM-BSE images (Figs. 4e and 4f). The white arrows in these two figures mark the altered lichen upper cortex and the exposed algae, responsible of the observed green colour of Figure $4 \mathrm{~b}$.

As the surface of $R$. disporum lichen colonized samples present a dark colour (Fig. 4a), it is expected that the IR laser mode $(1064 \mathrm{~nm})$ should be appropriate for removal, in similarity with the case of the dark V. nigrescens lichen species [32]. However, for the latter, as in the case of $A$. viridescens, a minimum fluence of $2 \mathrm{~J} \mathrm{~cm}^{-2}$ was necessary for complete removal. As this fluence overcomes the ablation threshold of sandstone it cannot be used in the present case. 

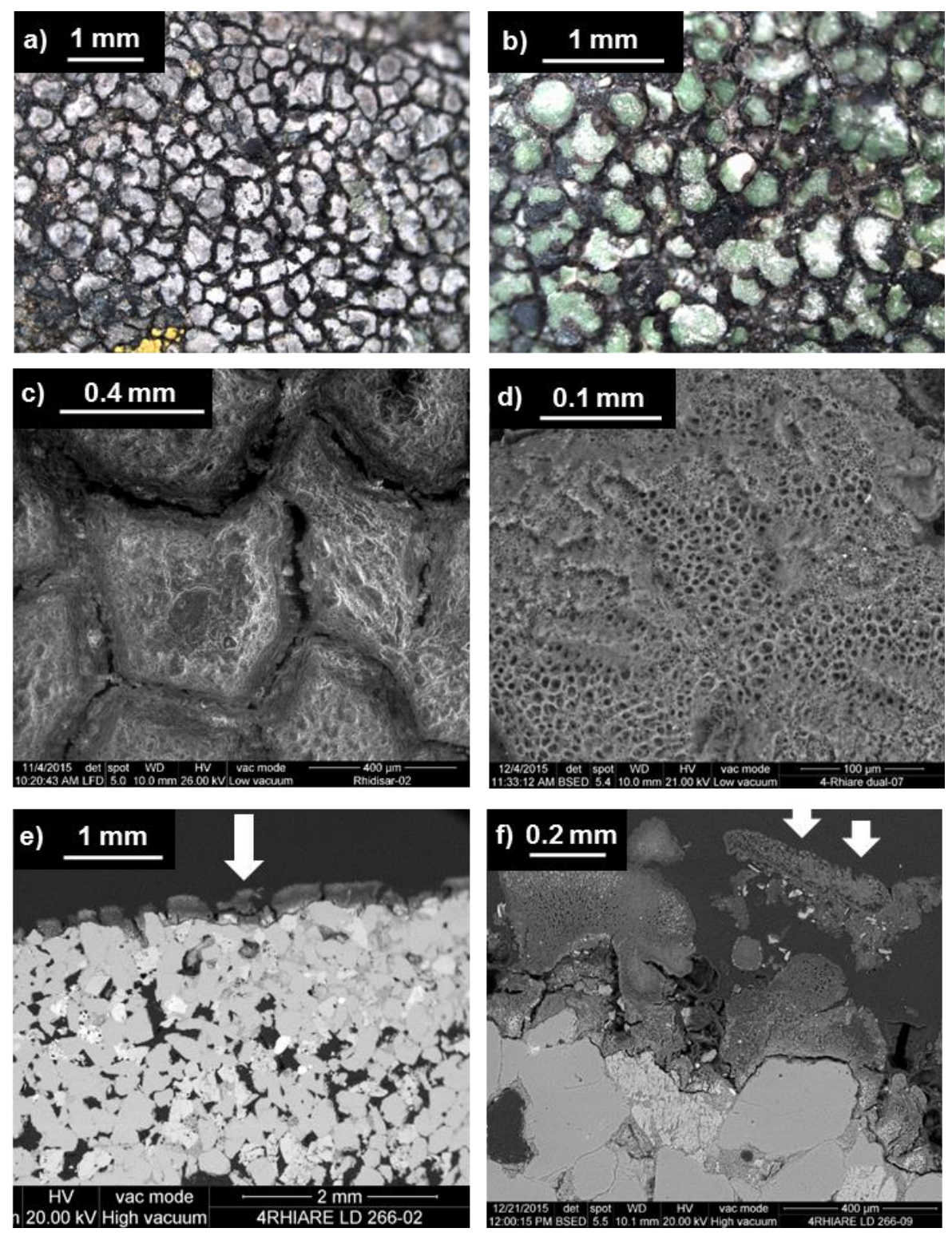

Fig. 4. Stereomicroscopy images of $R$. disporum on sandstone: a) non-treated and $\mathrm{b}$ ) treated by sequential IR-UV irradiation $(1064+266 \mathrm{~nm})$. SEM images of the surface of $R$. disporum on sandstone: c) nontreated and d) treated by sequential IR-UV irradiation. SEM-BSE images of the same sample after sequential IR-UV irradiation: e) general view and f) detailed view with high magnification. The white arrows mark the damaged lichen upper cortex and the exposed algae. For interpretation of the references to colour in this figure, the reader is referred to the web version of the article.

Results obtained in P. muralis on sandstone are exemplified in Figure 5. As seen in the stereomicroscopy image of Figure 5a, the thalli of this lichen species presents numerous apothecia. Single IR or UV laser irradiation (not shown) fails to remove both lichen apothecia and areoles, whereas sequential IR-UV $(1064+266 \mathrm{~nm})$ laser irradiation (Fig. 5b) leads to the partial removal of the upper cortex. Again, in this case, the green 
colour denotes the exposure of the algal layer on some areas of the surface of the treated part (white arrows). The effect of laser irradiation on the apothecia is limited and only amphitecial areas (peripheral parts) seem to be partly removed. The SEM-BSE image (Fig. 5c) confirms the elimination of the thalli vegetative parts under the present irradiation conditions (white arrow).
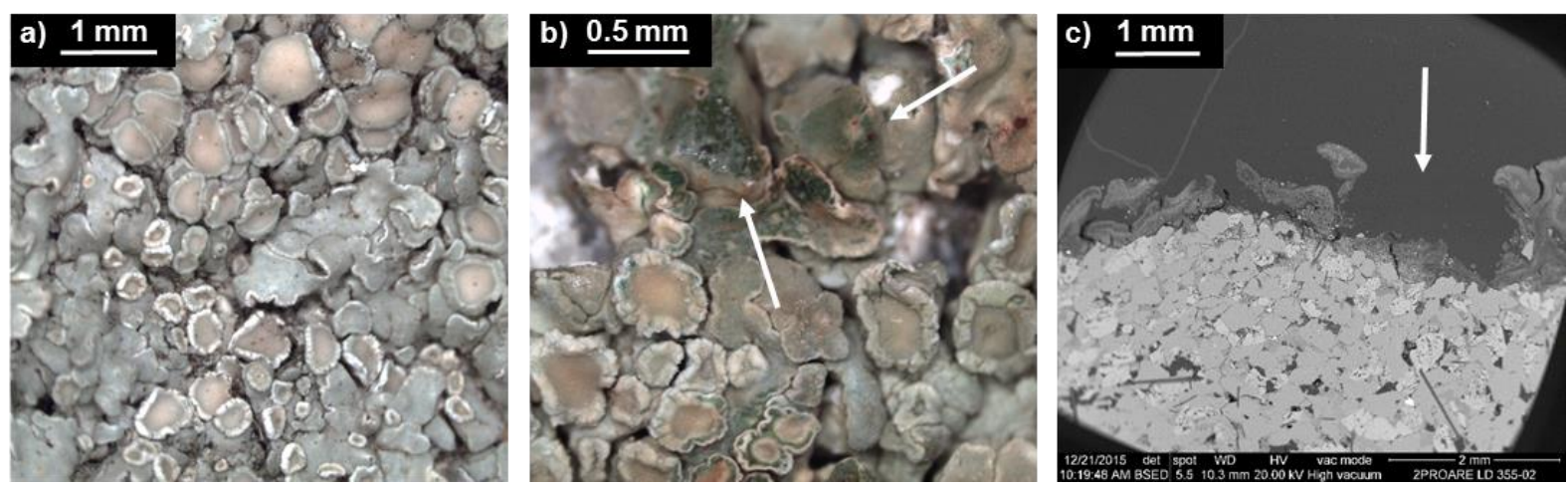

Fig. 5. Stereomicroscopy images of $P$. muralis on sandstone: a) non-treated and b) treated by sequential IR-UV irradiation $(1064+355 \mathrm{~nm})$, where the white arrows signal the partial removal of the cortex. c) SEM-BSE image of the lichen irradiated area, where the white arrow marks the partial elimination of the thalli. For interpretation of the references to colour in this figure, the reader is referred to the web version of the article.

Figure 6 displays the results obtained in P. cf. bolcana on granite. Fig. 6a shows nontreated lichen thalli covered by numerous apothecia. Sequential IR-UV $(1064+266 \mathrm{~nm})$ laser irradiation (Fig. 6b) partially removed the lichen upper cortex, exposing the green coloured algal layer. The SEM-BSE image of a cross-section (Fig. 6c) shows the elimination of some areoles (indicated by the white arrow), whereas in the image with a higher magnification (Fig. 6d) it is possible to also observe the elimination of fragments of the upper cortex and the structural damage inflicted on the thalli (also indicated by the white arrows). The inset in Figure 6d displays the EDS-mapped area of this image showing the calcium distribution inside the lichen (see comment in the following paragraphs). 

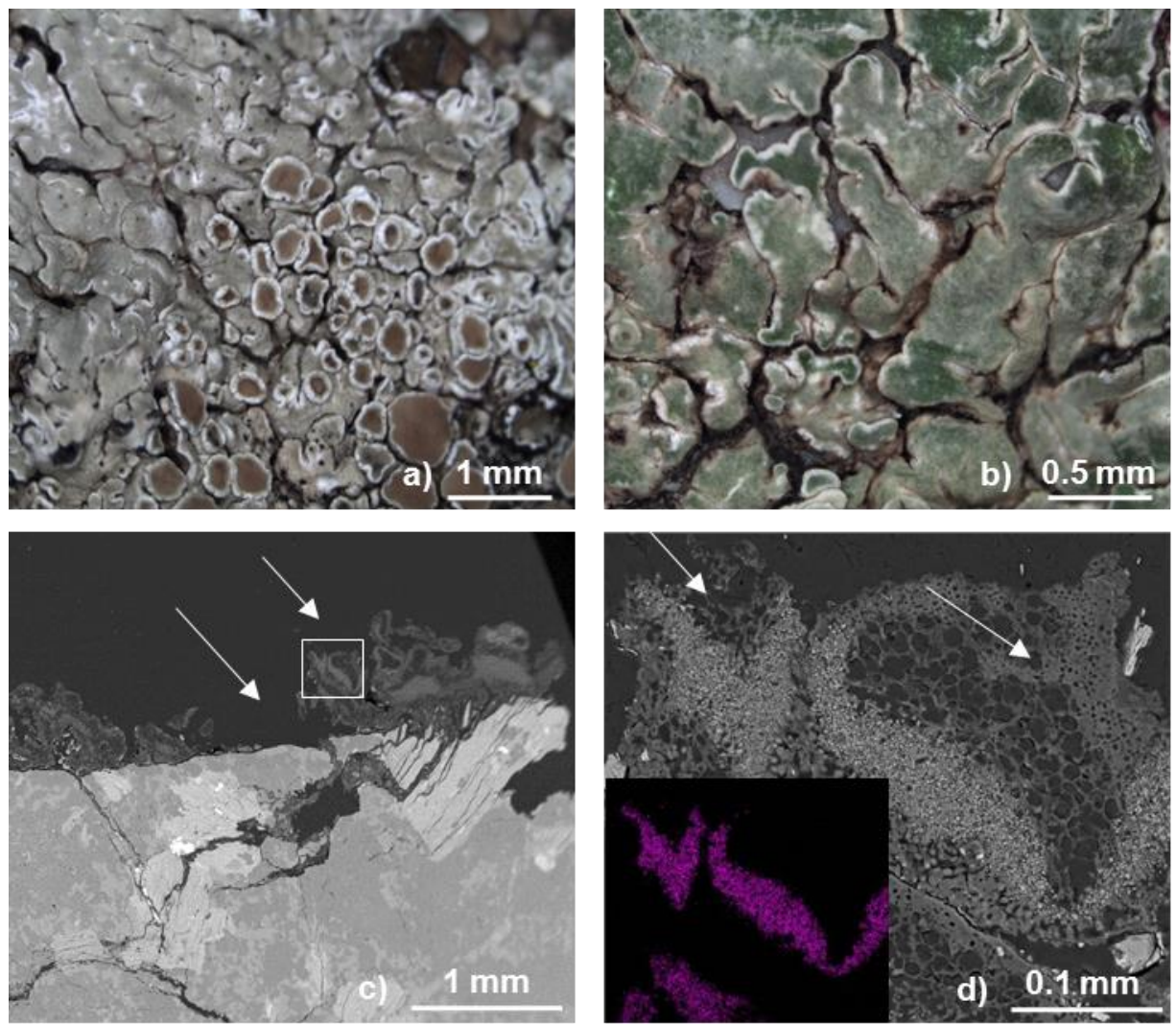

Fig. 6. Stereomicroscopy images of $P$. cf. bolcana on granite: a) non-treated and b) treated by sequential IR-UV (1064 + $266 \mathrm{~nm})$ irradiation. c) SEM-BSE image of the laser treated sample, d) high magnification SEM-BSE image of the square marked in c). The white arrows in c) and d) indicate damage on the thalli. The inset in d) displays the EDS-mapped area, showing the Ca distribution. For interpretation of the references to colour in this figure, the reader is referred to the web version of the article.

The analyzed Protoparmeliopsis lichen species ( $P$. muralis and $P$. cf. bolcana) present numerous apothecia on the thalli surface which respond differently than the rest of the thalli to laser irradiation. The effect of IR irradiation on the abundant apothecia is not totally efficient and only some parts of those elements are altered. On the other hand, UV irradiation (either at 266 and $355 \mathrm{~nm}$ ) induces a rather superficial damaging effect in the lichen thalli of both species. This effect is more pronounced at 266 than at 355 $\mathrm{nm}$, probably due to the higher absorption at the shorter wavelength (see Fig. 1). The combination of the two IR and UV wavelengths in the tested sequential dual irradiation of these lichen species brings a clear advantage with respect to the single IR or UV wavelength irradiation modes.

Figure 7 illustrates the case of $A$. cf. contorta on granite. As can be seen in the stereomicroscopy image (Fig. 7a) of a non-treated zone (left and above the red fringe) and of a zone treated by sequential IR-UV $(1064+266 \mathrm{~nm})$ irradiation (right and below 
the red fringe), laser irradiation induces the partial removal of the upper cortex and exposure of the algae. The SEM image of non-treated zone (Fig. 7b) shows the typical structure of the surface of the lichen upper cortex. After laser treatment the cortex appears clearly altered in the SEM images of the irradiated zone (Figs. 7c and 7d). Figure $7 \mathrm{c}$ shows the more uneven surface of the cortex present after irradiation, and in Fig. 7d it is shown that the algal layer is exposed in some parts of the thalli, in regions where the upper cortex was ablated during the laser treatment. This effect is shown in more detail in the SEM-BSE image (Fig. 7e), which displays the cortex deterioration and removal (white arrows), leaving exposed algal cells. Figure $7 \mathrm{f}$ shows a low magnification SEM-BSE image of the irradiated zone in which it is possible to observe the loss of fragments of upper cortex and damages in the algae layer, indicated by arrows. The inset on Figure $7 \mathrm{f}$ displays the EDS-mapped area corresponding to the square showing the calcium distribution inside the lichen thalli. IR-UV laser irradiation of $A$. cf. contorta on granite produces the best results in this lichen species. The alteration of the upper cortex and changes in the areoles structure are clearly observed. Here the lichen upper cortex is partially removed by the sequence of IR pulses and the exposed unprotected photobiont cells are eventually damaged by the following train of UV pulses. 

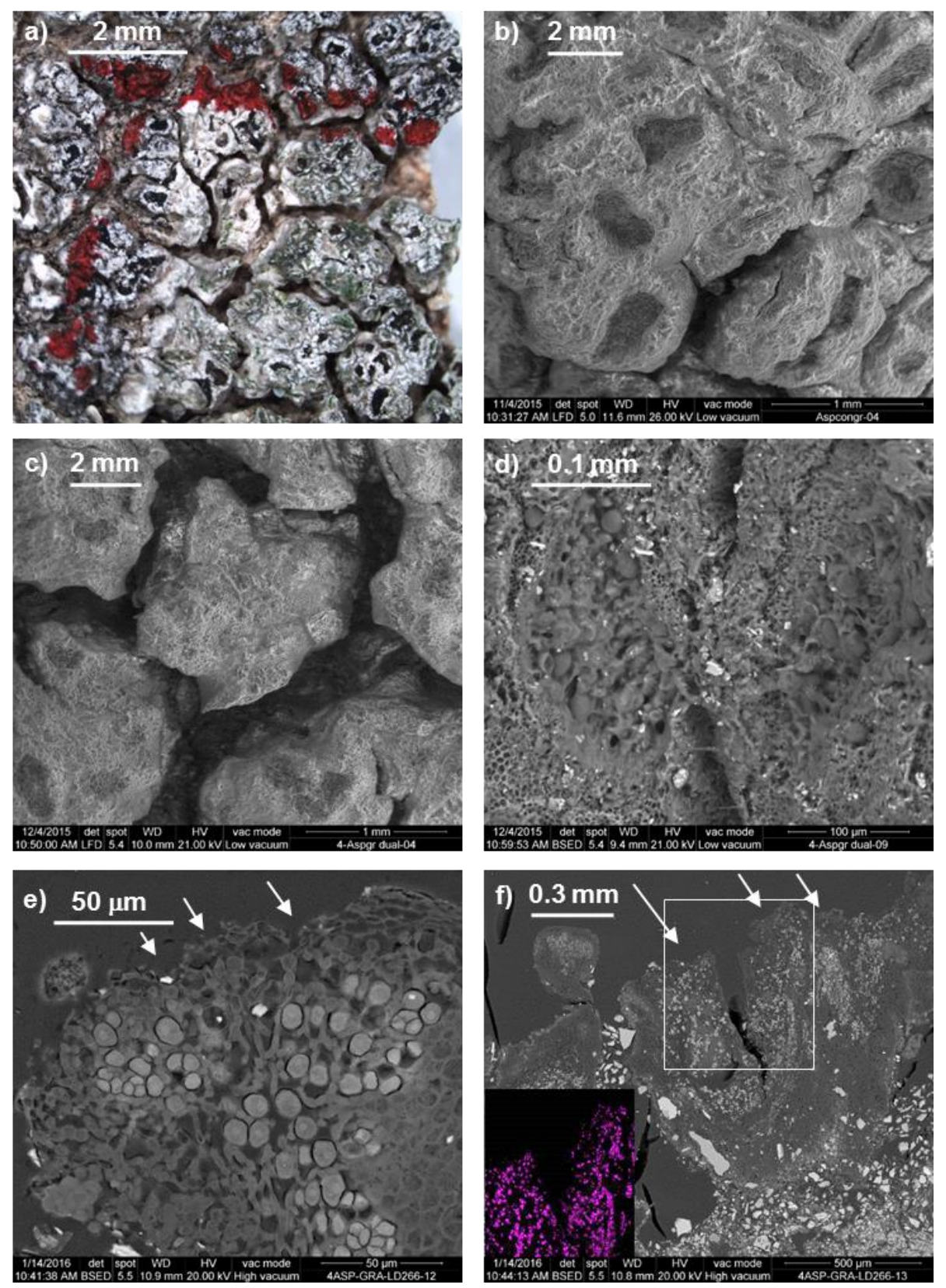

Fig. 7 Images of $A$. cf. contorta on granite: a) stereomicroscopy image of a non-treated zone (left and above the red fringe) and of a zone treated by sequential IR-UV $(1064+266 \mathrm{~nm})$ irradiation (right and below the red fringe), with the characteristic green colour. SEM images of the superficial area of the same sample: b) non-treated, c) and d) laser treated. In d) algal cells are observed. e) and f) SEM-BSE images of the same treated sample. The arrows in e) and f) mark the upper cortex with a high level of deterioration The inset in f) shows the corresponding EDS-mapped of the indicated square area, displaying the $\mathrm{Ca}$ distribution. For interpretation of the references to colour in this figure, the reader is referred to the web version of the article.

Sandstone and granite present different textures and slightly different chemical composition, factors that can influence on the lichen growth. Despite this differences, the laser cleaning effect appear quite similar for both substrates 
Additionally, in the case of the lichen species which are colonizing the granite substrate ( $P$. cf. bolcana and A. cf. contorta), the presence of calcium inside the lichens (Fig. 6d and $7 \mathrm{f}$ ), probably in the form of calcium oxalate due to the reaction between oxalic acid from the lichen and calcium from the substrate, could also prevent the laser damaging effect and thus action of irradiation only partially removed the upper cortex in the vegetative parts (areoles). It is worth noticing that, as it has been shown in Experimental section, the $\mathrm{CaO}$ concentration of granite is $2.45 \%$, whereas that of sandstone is 0.06 $\%$.

Table 3 summarizes the results obtained for the optimal laser treatment of each lichen species on the two different substrates.

Table 3. Summary of the results obtained after laser cleaning of lichens in different heritage stones. (S) stands for sandstone and $(\mathrm{G})$ for granite.

\begin{tabular}{|c|c|c|}
\hline Lichen & $\begin{array}{c}\text { Best irradiation } \\
\text { wavelength }\end{array}$ & Optimal results obtained \\
\hline $\begin{array}{l}\text { Candelariella } \\
\text { vitellina }(\mathrm{S})\end{array}$ & $\begin{array}{c}\text { UV } \\
(266 \mathrm{~nm})\end{array}$ & $\begin{array}{l}\text { Large areas of thalli completely removed. } \\
\text { Hymenial tissue partially ablated from lichen apothecia } \\
\text { inducing decolouration. }\end{array}$ \\
\hline $\begin{array}{l}\text { Aspicilia } \\
\text { viridescens }(\mathrm{S})\end{array}$ & $\begin{array}{c}\text { IR-UV } \\
(1064+266 \mathrm{~nm})\end{array}$ & $\begin{array}{l}\text { Complete removal of fragments of thalli and exposure of } \\
\text { fungi. } \\
\text { Decolouration of lichen apothecia. } \\
\text { Fungi exposed but fungi lipid bodies remain unaltered. }\end{array}$ \\
\hline $\begin{array}{l}\text { Rhizocarpon } \\
\text { disporum }(\mathrm{S})\end{array}$ & $\begin{array}{c}\text { IR-UV } \\
(1064+266 \mathrm{~nm})\end{array}$ & $\begin{array}{l}\text { Partial removal of upper cortex and exposure of algae } \\
\text { (green colour). } \\
\text { Elimination of fungal hyphae leaving small holes on } \\
\text { treated surface. }\end{array}$ \\
\hline $\begin{array}{l}\text { Protoparmeliopsis } \\
\text { muralis }(\mathrm{S})\end{array}$ & $\begin{array}{c}\text { IR-UV } \\
(1064+355 \mathrm{~nm})\end{array}$ & $\begin{array}{l}\text { Apothecia are not removed, only peripheral parts are } \\
\text { partially eliminated. } \\
\text { Elimination of thalli in vegetative parts. }\end{array}$ \\
\hline $\begin{array}{l}\text { Protoparmeliopsis } \\
\text { cf. bolcana }(\mathrm{G})\end{array}$ & $\begin{array}{c}\text { IR-UV } \\
(1064+266 \mathrm{~nm})\end{array}$ & $\begin{array}{l}\text { Elimination of upper cortex and exposure of algae (green } \\
\text { colour). } \\
\text { Removal of some areoles. }\end{array}$ \\
\hline $\begin{array}{l}\text { Aspicilia } \\
\text { cf. contorta }(\mathrm{G})\end{array}$ & $\begin{array}{c}\text { IR-UV } \\
(1064+266 \mathrm{~nm})\end{array}$ & $\begin{array}{l}\text { Partial removal of upper cortex and exposure of algae } \\
\text { (green colour). }\end{array}$ \\
\hline
\end{tabular}

\subsection{FT-Raman spectroscopy measurements}

We analyzed by FT-Raman spectroscopy the non-irradiated stone control areas and the areas where the laser treatment induced partial or complete elimination of the biodeteriogen film. As representative examples, FT-Raman spectra obtained on $C$. vitellina on sandstone and on $A$. cf. contorta on granite are shown in Figure 8 . The bands observed are listed in Table 4, together with their corresponding assignments. 
For sandstone (Fig. 8a), the Raman spectrum of the bare sandstone acquired in the back side of the sample (magenta line), displays the characteristic bands of $\alpha$-quartz (128, $207,267,355,465,510$, and $799 \mathrm{~cm}^{-1}$ ) [40], the main component of sandstone.

The spectrum of a non-irradiated zone with mixed microbial $C$. vitellina colonization (black line) presents small features attributed to the sandstone background at 463 and $506 \mathrm{~cm}^{-1}$ and additional bands assigned to the lichen compounds of C. vitellina [41-43], namely pulvinic dilactone (at 1406, 1603 and $1674 \mathrm{~cm}^{-1}$ ), calycin (at 1377 and $1632 \mathrm{~cm}^{-}$ ${ }^{1}$ ) and carotene, a compound produced by the lichen photobiont (at 1001, 1157, 1188 and $1524 \mathrm{~cm}^{-1}$ ). The presence of these lichen compounds has been also confirmed by TLC (see 3.1) and Table 1.

Additionally, in the spectrum of the non-treated area of the sample, some small features could be attributed to calcium oxalate monohydrate (whewellite) at 506, 1406, 1454 and $1632 \mathrm{~cm}^{-1}$. The band at $506 \mathrm{~cm}^{-1}$ coincides with a quartz band and those at 1406 and $1632 \mathrm{~cm}^{-1}$ match with bands of the lichen compounds, thus preventing the assignment. The intensity of the bands of the lichen compounds slightly increases upon laser irradiation of the colonized sample at $1064 \mathrm{~nm}$ (blue line), while the bands corresponding to the sandstone substrate weakly emerge in the spectrum. This supplies evidence of the partial removal of the lichen thalli which leaves exposed cells localized in internal layers of the lichen thalli. Figure 8 also displays the spectrum of a colonized sample zone after $266 \mathrm{~nm}$ laser irradiation (red line). In this case the bands of the bare sandstone can be observed. The Raman signal after sequential IR-UV $(1064+266 \mathrm{~nm})$ laser irradiation (green line) is very low, although a hint of lichen compounds bands is detected in the analyzed spectral zone. Although at the applied irradiation conditions the lichens are not completely removed, the biological layer is damaged and the surface does not yield a noticeable Raman response.

The FT-Raman results support the visual and stereomicroscopy observations (Fig. 2) performed on $C$. vitellina colonized sample, confirming the partial removal of the thalli upper cortex and exposure of the algal layer by irradiation at $1064 \mathrm{~nm}$ and the complete removal of fragments of thalli by irradiation at $266 \mathrm{~nm}$.

FT-Raman spectra were also obtained on A. cf. contorta on granite and are shown in Figure $8 \mathrm{~b}$. The FT-Raman spectrum of the bare granite acquired in the back side of the sample (magenta line), displays the characteristic bands of $\alpha$-quartz $(128,207,267,356$, 465, 699, 786, 1098 and $\left.1160 \mathrm{~cm}^{-1}\right)$ [40], plagioclase $\left(165,286,408,479\right.$ and $\left.509 \mathrm{~cm}^{-1}\right)$ 
[44] and $\mathrm{K}$ feldspar (286, 479 and $\left.509 \mathrm{~cm}^{-1}\right)$, the main components of this kind of granite [36].

The spectrum of a non-irradiated granite zone with mixed microbial $A$. cf. contorta colonization (black line) presents small features attributed to the granite background, as the band at $1081 \mathrm{~cm}^{-1}$, and additional bands assigned to chlorophyll (at 743, 1289 and $1383 \mathrm{~cm}^{-1}$ ) and carotene, a compound produced by the lichen photobiont (at 1003, 1157, 1188 and $1524 \mathrm{~cm}^{-1}$ ) [41]. Additionally, in the spectrum of the non-treated area of this sample, some weak bands could be attributed to calcium oxalate monohydrate (whewellite) at 1454 and $1632 \mathrm{~cm}^{-1}$.

The intensity of the bands of the biodeterioration layer clearly decreases upon laser irradiation of the colonized sample at $1064 \mathrm{~nm}$ (blue line), while the bands corresponding to whewellite weakly emerge in the spectrum. This supplies evidence of the partial removal of the lichen thalli. In the case of a colonized sample zone irradiated at $266 \mathrm{~nm}$ (red line), only bands of carotene are observed. The Raman signal after sequential IR-UV $(1064+266 \mathrm{~nm}$ ) laser irradiation (green line) is very low, although a hint of substrate and whewellite bands is detected in the analyzed spectral zone, indicating that the biological layer is clearly damaged and the surface does not yield a noticeable Raman response. These results support the stereomicroscopy and SEM images obtained on A.cf. contorta sample (Fig. 7), confirming the partial removal of the thalli upper cortex and exposure of Ca distribution by irradiation at $1064+266 \mathrm{~nm}$, without complete lichen removal.

In the spectra of the laser irradiated zones (Fig. 8) of both sandstone and granite substrates, no new peaks appear upon laser irradiation, indicating the absence of chemical changes in the stone substrate that could be induced by laser removal of microorganisms. 


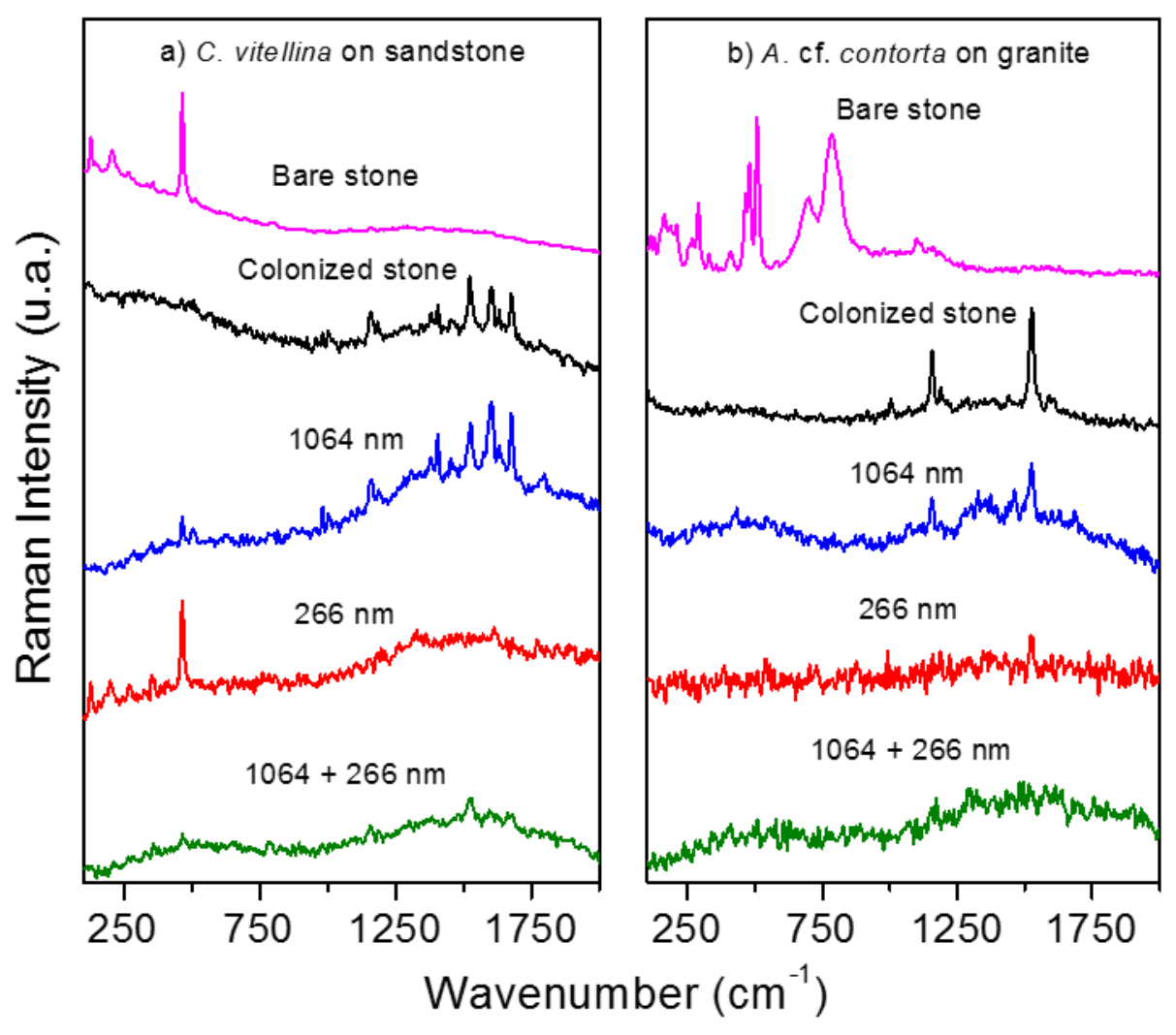

Fig. 8. FT-Raman spectra of a) C. vitellina on sandstone and b) A. cf. contorta on granite. The magenta line corresponds to the spectrum of the bare stone, and the black line to the spectrum of the surface colonized by the lichen before laser irradiation. The blue line is the spectrum of the colonized sample after laser irradiation at $1064 \mathrm{~nm}$, the red line corresponds to the sample irradiated at $266 \mathrm{~nm}$ and the green line is the spectrum of an area treated by sequential IR-UV $(1064+266 \mathrm{~nm})$ irradiation. For interpretation of the references to colour in this figure, the reader is referred to the web version of the article.

Table 4. Raman wavenumbers (in $\mathrm{cm}^{-1}$ ) and vibrational band assignment for the sandstone and granite samples and for the same samples colonized by $C$. vitellina and $A$. cf. contorta, respectively, under different laser irradiation conditions. 


\begin{tabular}{|c|c|c|c|c|c|}
\hline Sandstone & $\begin{array}{l}\text { C. Vitellina } \\
\text { Non-treated }\end{array}$ & 1064 nm & $266 \mathrm{~nm}$ & $\begin{array}{l}1064+ \\
266 \mathrm{~nm}\end{array}$ & Assignment \\
\hline & 1784 & 1796 & 1771 & & $v(\mathrm{CO})$ \\
\hline & 1674 & 1674 & 1611 & 1678 & $\begin{array}{l}v(\mathrm{CO}) \text { conjugated, free, pulvinic } \\
\text { dilactone }\end{array}$ \\
\hline & 1632 & 1630 & & & $\begin{array}{l}v(\mathrm{CO}) \text { conjugated, } \mathrm{H}-\text { bonded, calycin; } \\
v\left(\mathrm{CO}_{2}\right) \text { whewellite }\end{array}$ \\
\hline & 1603 & 1602 & & 1599 & $\begin{array}{l}v(\mathrm{CC}) \text { conjugated, aromatic, } \\
\text { pulvinic dilactone }\end{array}$ \\
\hline & & & 1580 & & G band, graphitic carbon \\
\hline & 1524 & 1524 & & 1526 & $v(\mathrm{CC})$ carotene \\
\hline & 1454 & 1454 & & & $v(\mathrm{CO})$ whewellite \\
\hline & 1406 & 1406 & & & $\begin{array}{l}\omega\left(\mathrm{CO}_{2}\right) \text { whewellite; } \\
\text { pulvinic dilactone }\end{array}$ \\
\hline & 1377 & 1377 & & 1383 & $\delta(\mathrm{CO})$ phenyl, calycin \\
\hline & 1188 & 1188 & & 1186 & ring stretch, carotene \\
\hline & & & 1340 & & D band, disordered carbon \\
\hline & 1157 & 1159 & & 1157 & $v(\mathrm{CC})$ stretching, carotene \\
\hline & 1001 & 1001 & & & $v(\mathrm{CC})$ ring breathing, carotene \\
\hline 799 & & & & & $\mathrm{SiO}_{2}$ stretching, $\alpha$-quartz \\
\hline 510 & 506 & 504 & & & $\begin{array}{l}\delta\left(\mathrm{CO}_{2}\right) \text { whewellite; } \\
\mathrm{SiO}_{2} \text { bending, } \alpha \text {-quartz }\end{array}$ \\
\hline 465 & 463 & 465 & 465 & 465 & $\mathrm{SiO}_{2}$ bending, $\alpha$-quartz \\
\hline 355 & & 352 & 355 & & $\mathrm{SiO}_{2}$ bending, $\alpha$-quartz \\
\hline 267 & & & 269 & & $\mathrm{SiO}_{2}$ twisting, $\alpha$-quartz \\
\hline 207 & & & 199 & & $\mathrm{SiO}_{2}$ twisting, $\alpha$-quartz \\
\hline 128 & & & 128 & & $\mathrm{SiO}_{2}$ twisting, $\alpha$-quartz \\
\hline \multirow[t]{5}{*}{ Granite } & $\begin{array}{l}\text { A. cf. contorta } \\
\text { Non-treated }\end{array}$ & & & & \\
\hline & 1632 & 1630 & & & $v\left(\mathrm{CO}_{2}\right)$ whewellite \\
\hline & 1524 & 1524 & 1522 & 1512 & $v(\mathrm{CC})$ carotene \\
\hline & 1454 & 1460 & & 1470 & $v(\mathrm{CO})$ whewellite \\
\hline & 1188 & 1188 & 1188 & 1186 & ring stretching, carotene \\
\hline \multirow[t]{4}{*}{1160} & & & & & $\mathrm{SiO}_{2}$ bending, $\alpha$-quartz \\
\hline & 1157 & 1156 & & 1167 & $v(\mathrm{CC})$ stretching, carotene \\
\hline & 1383 & 1373 & 1372 & & $\delta\left(\mathrm{CH}_{2}\right)$ chlorophyll \\
\hline & 1289 & & & & $\delta\left(\mathrm{CH}_{2}\right)$ chlorophyll \\
\hline \multirow[t]{3}{*}{1098} & 1081 & 1079 & & & $\mathrm{SiO}_{2}$ asymmetric stretching, $\alpha$-quartz \\
\hline & 1003 & 1001 & 994 & & $v(\mathrm{CC})$ ring breathing, carotene \\
\hline & & & & 886 & whewellite \\
\hline \multirow[t]{2}{*}{786} & & & & & $\mathrm{SiO}_{2}$ stretching, $\alpha$-quartz \\
\hline & 743 & & & & Ring breathing, chlorophyll \\
\hline 699 & & & & & $\mathrm{SiO}_{2}$ stretching, $\alpha$-quartz \\
\hline 509 & & & & 510 & $\begin{array}{l}\mathrm{SiO}_{2} \text { stretching, plagioclase, } \mathrm{K} \text {-feldspar, } \\
\delta\left(\mathrm{CO}_{2}\right) \text { whewellite }\end{array}$ \\
\hline 479 & & & & & $\mathrm{SiO}_{2}$ stretching, plagioclase, $\mathrm{K}$-feldspar \\
\hline 465 & & & & & $\mathrm{SiO}_{2}$ bending, $\alpha$-quartz \\
\hline 408 & & & & 413 & Lattice vibration, plagioclase \\
\hline 356 & & & & & $\mathrm{SiO}_{2}$ vibration, $\alpha$-quartz \\
\hline 286 & & & & & Lattice vibration, plagioclase, K-feldspar \\
\hline 267 & & & & & $\mathrm{SiO}_{2}$ twisting, $\alpha$-quartz \\
\hline 207 & & & & & $\mathrm{SiO}_{2}$ twisting, $\alpha$-quartz \\
\hline 165 & & & & & Lattice vibration, plagioclase \\
\hline 128 & & & & & $\mathrm{SiO}_{2}$ twisting, $\alpha$-quartz \\
\hline
\end{tabular}


For the rest of the studied lichens (not shown), FT-Raman spectra of the doubly irradiated areas display the features of the substrates, thus confirming partial removal of the biodeteriogen layer as observed by stereomicroscopy and SEM-BSE. Also no new peaks appear upon laser irradiation in any of the used conditions.

\section{Conclusions}

In this work we have investigated the use of Q-switched Nd:YAG laser delivering nanosecond pulses for the elimination of epilithic crustose lichen layers from heritage samples of sandstone and granite. Specifically, we compared different modes based on single-wavelength irradiation, either in the IR, at $1064 \mathrm{~nm}$, in the UV, at 355 or $266 \mathrm{~nm}$, and on dual sequential irradiation, with IR followed by UV pulses. The results obtained indicate that the optimal conditions for laser removal of the biodeteriogen layers are highly dependent on the lichen species treated and much less on the type of stone substrate.

In the case of lichen species with high absorption in the UV region, as Candelariella vitellina, the optimal cleaning conditions were obtained at $266 \mathrm{~nm}$, which resulted in the partial removal of the upper cortex, exposure of the algae in some areas and complete removal of fragments of thalli in other areas. In Protoparmeliopsis species ( $P$. muralis and $P$. cf. bolcana), the sequential IR-UV $(1064+355$ or $266 \mathrm{~nm})$ laser irradiation partially removed the thalli upper cortex in the vegetative parts of the lichen (areoles). However, the damage inflicted in the apothecia was found minimal, possibly due to the highly efficient protective role of their sterile elements.

For the rest of studied lichens on sandstone (A. viridescens and $R$. disporum), the sequential IR-UV $(1064+266 \mathrm{~nm})$ laser irradiation was also found to be the most appropriate irradiation mode because it leads to the partial removal of the thalli areoles, to the exposure of medullar fungal cells and, in some cases, the complete removal of fragments of thalli.

In the case of the analyzed lichen species on granite ( $P$. cf. bolcana and A. cf. contorta), the presence of calcium inside the lichen thalli, probably due to the reaction between oxalic acid from the lichen and calcium from the substrate, is thought to prevent the damaging effect of laser irradiation. In these cases, the laser effect consists in the partial removal of the thalli upper cortex from vegetative parts (areoles). 
In the studied lichen species, it has been found that the laser treatment does not lead to the complete removal of lichen thalli, but it clearly induces various types and degrees of damage, including the loss of the upper cortex and dramatic effects on the algal layer. In the medium term, these alterations could eventually result in the destruction of the lichen thalli, thus providing a high degree of control of the biodeterioration processes of the lithic substrate and reducing the chances of lichen recolonization.

\section{Acknowledgements}

The present work was supported by programs Geomateriales 2 (S2013/MIT-2914) financed by Comunidad de Madrid and Structural Funds (FSE and FEDER) and IPERION-CH Ref. H2020-INFRAIA-2014-2015, nº 654028. MO thanks CSIC for contract. SPO is supported by the Spanish Ministry of Economy and Competitiveness (MINECO) grant RYC-2014-16784. We are grateful to M. Furio, A. Jorge and L. Tormo from Servicio de Microscopía, MNCN-CSIC.

\section{References}

[1] G. Caneva, M. Nugari, O. Salvadori, Control of biodeterioration and bioremediation techniques, Plant Biology for Cultural Heritage: Biodeterioration and Conservation, Getty Conservation Institute, Los Angeles, (2008) 309-346.

[2] C.A. Price, E. Doehne, Stone conservation: an overview of current research, Getty Publications, 2011.

[3] K. Sterflinger, G. Piñar, Microbial deterioration of cultural heritage and works of art-tilting at windmills?, Applied microbiology and biotechnology, 97 (2013) 96379646.

[4] N.A. Cutler, H.A. Viles, S. Ahmad, S. McCabe, B.J. Smith, Algal 'greening' and the conservation of stone heritage structures, Science of The Total Environment, 442 (2013) 152-164.

[5] V. Lamprinou, M. Mammali, E.A. Katsifas, A.I. Pantazidou, A.D. Karagouni, Phenotypic and molecular biological characterization of cyanobacteria from marble surfaces of treated and untreated sites of Propylaea (Acropolis, Athens), Geomicrobiology Journal, 30 (2013) 371-378.

[6] C. Ascaso, J. Wierzchos, R. Castello, Study of the biogenic weathering of calcareous litharenite stones caused by lichen and endolithic microorganisms, International Biodeterioration and Biodegradation, 42 (1998) 29-38.

[7] C. Ascaso, J. Wierzchos, V. Souza-Egipsy, A. de los Rios, J.D. Rodrigues, In situ evaluation of the biodeteriorating action of microorganisms and the effects of biocides on carbonate rock of the Jeronimos Monastery (Lisbon), International Biodeterioration \& Biodegradation, 49 (2002) 1-12.

[8] C. Ascaso, J. Wierzchos, Study of the biodeterioration zone between the lichen thallus and the substrate, Cryptogamic Botany, 5 (1995) 270-281. 
[9] A. De los Rios, C. Ascaso, Contributions of in situ microscopy to the current understanding of stone biodeterioration, International Microbiology, 8 (2005) 181-188.

[10] A. DeCruz, M.L. Wolbarsht, R.A. Palmer, S.E. Pierce, E. Adamkiewicz, Er : YAG laser applications on marble and limestone sculptures with polychrome and patina surfaces, in: K. Dickman, C. Fotakis, J.F. Asmus (Eds.) Lasers in the Conservation of Artworks, 2005, pp. 113-124.

[11] B. Cámara, A. De los Ríos, M. Urizal, M.Á. De Buergo, M.J. Varas, R. Fort, C. Ascaso, Characterizing the microbial colonization of a dolostone quarry: implications for stone biodeterioration and response to biocide treatments, Microbial Ecology, 62 (2011) 299-313.

[12] A. De los Ríos, S. Pérez-Ortega, J. Wierzchos, C. Ascaso, Differential effects of biocide treatments on saxicolous communities: case study of the Segovia cathedral cloister (Spain), International Biodeterioration \& Biodegradation, 67 (2012) 64-72. [13] R. Pini, S. Siano, R. Salimbeni, V. Piazza, M. Giamello, G. Sabatini, F. Bevilacqua, Application of a new laser cleaning procedure to the mausoleum of Theodoric, Journal of Cultural Heritage, 1 (2000) S93-S97.

[14] G. Marakis, P. Pouli, V. Zafiropulos, P. Maravelaki-Kalaitzaki, Comparative study on the application of the 1 st and the 3 rd harmonic of a Q-switched Nd: YAG laser system to clean black encrustation on marble, Journal of Cultural Heritage, 4 (2003) 8391.

[15] P. Maravelaki-Kalaitzaki, V. Zafiropulos, P. Pouli, D. Anglos, C. Balas, R. Salimbeni, S. Siano, R. Pini, Short free running Nd: YAG laser to clean different encrustations on Pentelic marble: procedure and evaluation of the effects, Journal of Cultural Heritage, 4 (2003) 77-82.

[16] M. Oujja, E. Rebollar, M. Castillejo, C. Domingo, C. Cirujano, F. Guerra-Librero, Laser cleaning of terracotta decorations of the portal of Palos of the Cathedral of Seville, Journal of Cultural Heritage, 6 (2005) 321-327.

[17] S. Potgieter-Vermaak, R. Godoi, R. Van Grieken, J. Potgieter, M. Oujja, M. Castillejo, Micro-structural characterization of black crust and laser cleaning of building stones by micro-Raman and SEM techniques, Spectrochimica Acta Part A: Molecular and Biomolecular Spectroscopy, 61 (2005) 2460-2467.

[18] C. Fotakis, D. Anglos, V. Zafiropulos, S. Georgiou, V. Tornari, Lasers in the preservation of cultural heritage: Principles and applications, CRC Press, 2006.

[19] P. Pouli, C. Fotakis, B. Hermosin, C. Sáiz-Jiménez, C. Domingo, M. Oujja, M. Castillejo, The laser-induced discoloration of stonework; a comparative study on its origins and remedies, Spectrochimica Acta Part A: Molecular and Biomolecular Spectroscopy, 71 (2008) 932-945.

[20] S. Siano, R. Salimbeni, Advances in laser cleaning of artwork and objects of historical interest: the optimized pulse duration approach, Accounts of chemical research, 43 (2010) 739-750.

[21] S. Siano, J. Agresti, I. Cacciari, D. Ciofini, M. Mascalchi, I. Osticioli, A. Mencaglia, Laser cleaning in conservation of stone, metal, and painted artifacts: state of the art and new insights on the use of the Nd: YAG lasers, Applied Physics A, 106 (2012) 419-446.

[22] G. Senesi, I. Carrara, G. Nicolodelli, D. Milori, O. De Pascale, Laser cleaning and laser-induced breakdown spectroscopy applied in removing and characterizing black crusts from limestones of Castello Svevo, Bari, Italy: A case study, Microchemical Journal, 124 (2016) 296-305. 
[23] M. Wolbarsht, R. Palmer, S. Pierce, E. Adamkiewicz, Er: YAG laser applications on marble and limestone sculptures with polychrome and patina surfaces, in: Lasers in the Conservation of Artworks, Springer, 2005, pp. 113-124.

[24] P. Maravelaki-Kalaitzaki, V. Zafiropulos, C. Fotakis, Excimer laser cleaning of encrustation on Pentelic marble: procedure and evaluation of the effects, Applied Surface Science, 148 (1999) 92-104.

[25] J.S. Pozo-Antonio, T. Rivas, A.J. López, M.P. Fiorucci, A. Ramil, Effectiveness of granite cleaning procedures in cultural heritage: A review, Science of The Total Environment, 571 (2016) 1017-1028.

[26] K. Nandakumar, H. Obika, A. Utsumi, T. Ooie, T. Yano, In vitro laser ablation of natural marine biofilms, Applied and environmental microbiology, 70 (2004) 69056908.

[27] K. Nandakumar, H. Obika, A. Utsumi, T. Ooie, T. Yano, Molecular level damages of low power pulsed laser radiation in a marine bacterium Pseudoalteromonas carrageenovora, Letters in applied microbiology, 42 (2006) 521-526.

[28] A. DeCruz, M.L. Wolbarsht, A. Andreotti, M.P. Colombini, D. Pinna, C.F. Culberson, Investigation of the Er: YAG laser at $2.94 \mu \mathrm{m}$ to remove lichens growing on stone, Studies in Conservation, 54 (2009) 268-277.

[29] P. Leavengood, J. Twilley, J.F. Asmus, Lichen removal from Chinese Spirit Path figures of marble, Journal of Cultural Heritage, 1 (2000) S71-S74.

[30] I. Osticioli, M. Mascalchi, D. Pinna, S. Siano, Removal of Verrucaria nigrescens from Carrara marble artefacts using Nd:YAG lasers: comparison among different pulse durations and wavelengths, Applied Physics A, 118 (2014) 1517-1526.

[31] M. Sanz, M. Oujja, C. Ascaso, A. de los Ríos, S. Pérez-Ortega, V. Souza-Egipsy, J. Wierzchos, M. Speranza, M.V. Cañamares, M. Castillejo, Infrared and ultraviolet laser removal of crustose lichens on dolomite heritage stone, Applied Surface Science, 346 (2015) 248-255.

[32] M. Speranza, M. Sanz, M. Oujja, A. De los Rios, J. Wierzchos, S. Pérez-Ortega, M. Castillejo, C. Ascaso, Nd-YAG laser irradiation damages to Verrucaria nigrescens, International Biodeterioration \& Biodegradation, 84 (2013) 281-290.

[33] E. Sarantopoulou, Z. Kollia, I. Gomoiu, Preventing biological activity of Ulocladium sp spores in artifacts using 157-nm laser, Applied Physics A, 83 (2006) 663-668.

[34] M. Mascalchi, I. Osticioli, C. Riminesi, O.A. Cuzman, B. Salvadori, S. Siano, Preliminary investigation of combined laser and microwave treatment for stone biodeterioration, Studies in Conservation, 60 (2015) S19-S27.

[35] E.S. Pérez, J.A.G. Barrera, R. Fort, P.L.Y. Hoyal, M. Bustillo, Estado actual de los estudios de conservación de las pinturas rupestres esquemáticas del Monte Valonsadero (Soria) y propuestas para su protección y salvaguarda, Espacio Tiempo y Forma. Serie I, Prehistoria y Arqueología, 13 (2000) 189-252.

[36] D. Freire-Lista, R. Fort, M. Varas-Muriel, Alpedrete Granite (Spain). A Nomination for the" Global Heritage Stone Resource" Designation, Episodes, 38 (2015) 106-113.

[37] A. Orange, P.W. James, F. White, Microchemical methods for the identification of lichens, Twayne Publishers, 2001.

[38] J. Wierzchos, C. Ascaso, Application of back-scattered electron imaging to the study of the lichen-rock interface, Journal of Microscopy, 175 (1994) 54-59.

[39] K.-H. Nguyen, M. Chollet-Krugler, N. Gouault, S. Tomasi, UV-protectant metabolites from lichens and their symbiotic partners, Natural product reports, 30 (2013) 1490-1508. 
[40] J. Etchepare, M. Merian, L. Smetankine, Vibrational normal modes of SiO2. I. $\alpha$ and $\beta$ quartz, The Journal of Chemical Physics, 60 (1974) 1873-1876.

[41] S.E.J. Villar, H.G. Edwards, M.R. Seaward, Raman spectroscopy of hot desert, high altitude epilithic lichens, Analyst, 130 (2005) 730-737.

[42] H. Edwards, N. Russell, M. Seaward, Calcium oxalate in lichen biodeterioration studied using FT-Raman spectroscopy, Spectrochimica Acta Part A: Molecular and Biomolecular Spectroscopy, 53 (1997) 99-105.

[43] H.G. Edwards, M.R. Seaward, S.J. Attwood, S.J. Little, L.F. de Oliveira, M. Tretiach, FT-Raman spectroscopy of lichens on dolomitic rocks: an assessment of metal oxalate formation, Analyst, 128 (2003) 1218-1221.

[44] S.K. Sharma, S.M. Angel, M. Ghosh, H.W. Hubble, P.G. Lucey, Remote Pulsed Laser Raman Spectroscopy System for Mineral Analysis on Planetary Surfaces to 66 Meters, Applied Spectroscopy, 56 (2002) 699-705. 